\title{
Mechanisms Regulating the Cardiac Output Response to Cyanide Infusion, a Model of Hypoxia
}

\author{
Chang-seng Liang and Winliam E. Huckabee \\ From the Departments of Medicine and Pharmacology, Boston University \\ School of Medicine and the Departments of Medicine and Clinical Research, \\ University Hospital, Boston, Massachusetts 02118
}

A B S T R A C T When tissue metabolic changes like those of hypoxia were induced by intra-aortic infusion of cyanide in dogs, cardiac output began to increase after 3 to $5 \mathrm{~min}$, reached a peak ( $220 \%$ of the control value) at 15 min, and returned to control in $40 \mathrm{~min}$. This pattern of cardiac output rise was not altered by vagotomy with or without atropine pretreatment. However, this cardiac output response could be differentiated into three phases by pretreating the animals with agents that block specific activities of the sympatho-adrenal system. First, ganglionic blockade produced by mecamylamine or sympathetic nerve blockade by bretylium abolished the middle phase of the cardiac output seen in the untreated animal, but early and late phases still could be discerned. Second, beta-adrenergic receptor blockade produced by propranolol shortened the total duration of the cardiac output rise by abolishing the late phase. Third, when given together, propranolol and mecamylamine (or bretylium) prevented most of the cardiac output rise that follows the early phase.

When cyanide was given to splenectomized dogs, the duration of the cardiac output response was not shortened, but the response became biphasic, resembling that seen after chemical sympathectomy. A similar biphasic response of the cardiac output also resulted from splenic denervation; sham operation or nephrectomy had no effect on the monophasic pattern of the normal response. Splenic venous blood obtained from cyanide-treated dogs, when infused intraportally, caused an increase in cardiac

Preliminary reports were read before the Federation of American Societies for Experimental Biology in Atlantic City, New Jersey, April 15, 1970 (Fed. Proc. 29: 525 Abstr.) and in Chicago, Illinois, April 17, 1971 (Fed. Proc. 30: 660 Abstr.).

Submitted by Dr. Liang in partial fulfillment of the requirements for the degree of Doctor of Philosophy at the Boston University Graduate School.

Received for publication 12 March 1973 and in revised form 16 July 1973.

The Journal of Clinical Investigation output in recipient dogs; similar infusion of arterial blood had no effects.

These results suggest that the cardiac output response to cyanide infusion consists of three components: an early phase, related neither to the autonomic nervous system nor to circulating catecholamines; a middle phase, caused by a nonadrenergic humoral substance released from the spleen by sympathetic stimulation; and a late phase, dependent upon adrenergic receptors but not upon sympathetic transmission.

\section{INTRODUCTION}

The increase in cardiac output observed during hypoxia presumably is related either entirely or in part to reduction in tissue oxygen tension. However, since tissue hypoxia is associated with a variety of changes in tissue energy metabolism, these biochemical alterations, rather than the low tissue oxygen tension itself, may be responsible for the circulatory stimulation. In order to test this hypothesis, one of us ${ }^{1}$ infused cyanide intra-aortically into dogs to induce metabolic changes like those occurring in hypoxia, while at the same time allowing the dogs to breathe oxygen to keep oxygen tension normal or above normal in all parts of the body. Indeed, cardiac output increased after such an infusion, and changes in heart rate and in arterial and ventricular pressures were qualitatively similar to those which occur during respiratory hypoxemia. It was also found that an intra-aortic infusion of cyanide $(0.04 \mathrm{mmol} / \mathrm{kg}$ in $5 \mathrm{~min})$ sufficient to triple the cardiac output did not give rise to a measurable amount of cyanide in the right ventricular blood. The smallest measurable concentration of cyanide $(0.009$ $\mathrm{mM}$ ) produced no effects in a Starling heart-lung preparation. This experimental model of hypoxia offers the

${ }^{1}$ Huckabee, W. E. Metabolic factors in cardiac output control. Manuscript in preparation. 
important advantage that no significant amount of cyanide reaches the heart to impair myocardial oxygen utilization and contractility, whereas myocardial hypoxia may occur during hypoxemia. Other advantages offered by this method are that it is technically simple and that it permits reproducible increases in cardiac output in intact dogs.

This investigation was designed to elucidate the mechanisms by which cardiac output increases during cyanide-induced tissue hypoxia. Since the autonomic nervous system is known to influence cardiac function (1), experiments were designed to study the role of the autonomic nervous system in regulating the cardiac output response to cyanide. Furthermore, we have demonstrated recently that the spleen contains a cardiostimulatory substance (2), confirming the earlier reports of Rein, Mertens, and Bücherl (3). Because the spleen has been shown to play an important role in circulatory regulation during hypoxemia and coronary occlusion $(3,4)$, we also carried out experiments to study the role of the spleen and its mechanism of action in the regulation of cardiac output after cyanide infusion.

\section{METHODS}

Dogs of various strains and of both sexes, weighing between 10 and $27.5 \mathrm{~kg}$, were used. Anesthesia was induced with methoxyflurane and maintained with intravenous chloralose $(50-60 \mathrm{mg} / \mathrm{kg})$. The trachea was cannulated and connected to a 9-liter Benedict-Roth spirometer. A femoral artery was cannulated for measuring arterial blood pressure. A second catheter was inserted into the other femoral artery and advanced a length that approximated in each dog the distance between the point of insertion and the xiphoid process. This catheter was used for infusing cyanide, and the position of its tip was later confirmed at autopsy. The right ventricle was cannulated via the right external jugular vein for sampling blood, injecting indocyanine green (Cardio-Green, Hynson, Westcott \& Dunning, Inc., Baltimore, $\mathrm{Md}$.), and measuring right ventricular pressure. The frequency response of this catheter, measured by a square wave impulse, was $13 \mathrm{~Hz}$. A carotid artery was cannulated for sampling arterial blood. Heparin $(500 \mathrm{U} / \mathrm{kg})$ was administered after the surgery to prevent blood from clotting.

Blood pressures were measured with Sanborn 267-AC pressure transducers and recorded on a Sanborn 7700 recorder (Hewlett-Packard Co., Waltham Div., Waltham, Mass.). Heart rate was calculated from blood pressure tracings. Cardiac output was measured by both direct Fick and dye-dilution techniques. The Fick method entailed simultaneously drawing $5 \mathrm{ml}$ samples of right ventricular and arterial blood over a period of $2 \frac{1}{2} \mathrm{~min}$ while the rate of oxygen consumption was recorded on the spirometer. The blood samples were promptly analyzed for oxygen content by a gas chromatographic method (5), which was found to be in good agreement with Van Slyke and Neill's method (6). The dye-dilution method used was essentially similar to that of Shadle, Ferguson, Gregg, and Gilford (7), employing a Gilford Colson 103 densitometer (Gilford Instrument Laboratories, Inc., Oberlin, Ohio). For cardiac output determinations, a known amount of indocyanine green was injected into the right ventricle with a precision syringe and flushed with saline, while arterial blood was withdrawn continuously from the carotid artery through the cuvette of the densitometer by a Harvard pump (Harvard Apparatus Co., Millis, Mass.) at a rate of 21 $\mathrm{ml} / \mathrm{min}$, and the dye curve was registered on a HewlettPackard 1701 BM strip chart recorder. The dye curve was corrected for recirculation of the dye and the area measured planimetrically. For each dog a calibration line was obtained by passing bloods of three known dye concentrations through the densitometer; the slope of the line gave the factor for converting the dye curve area to cardiac output. We have previously established that the values of repetitive measurements of dye cardiac outputs fall within $6 \%$ of the mean and they agree with Fick cardiac outputs with a mean difference of only $4.28 \%$ (8).

Arterial blood samples were collected and measured for lactate and pyruvate as reported by Huckabee (9). Blood oxygen capacity was determined by a cyanmethemoglobin method (10). Blood $\mathrm{pH}$ was measured on a Radiometer PHM $26 \mathrm{pH}$ meter (The London Company, Westlake, Ohio).

Experimental design. Each dog was infused only once with a standard dose of cyanide. Sodium cyanide was diluted with distilled water and the cyanide solution was infused intra-aortically at a rate of $1.91 \mathrm{ml} / \mathrm{min}$ with the concentration adjusted for each dog to infuse a total amount of $0.03 \mathrm{mmol} / \mathrm{kg}$ in $6 \mathrm{~min}$. Blood pressures, oxygen consumption, and heart rate were recorded continuously throughout the experiment. Fick cardiac outputs, measured at 15,25 , and $40 \mathrm{~min}$ after the start of cyanide infusion, were used for statistical comparisons (Tables I and IV). Dye cardiac outputs, on the other hand, were measured every 3-5 min to supplement the Fick outputs in following the changes in cardiac output that occurred in animals as a result of cyanide infusion (Figs. 1-3). Arterial blood samples for $\mathrm{pH}$, and lactate and pyruvate determinations were obtained every 5-10 min during the hour after the start of cyanide infusion.

In-addition to the control experiments conducted in intact dogs, several procedures were undertaken to eliminate one or several functions of the automatic nervous system so that its role in cardiac output regulation could be studied. Parasympathetic activity was eliminated by cervical vagotomy with or without atropine $(0.5 \mathrm{mg} / \mathrm{kg}$, i.v.) pretreatment, and sympathetic activity by chemical agents that interrupt the integrity of sympathetic function at different sites. These agents and their doses were as follows: mecamylamine hydrochloride, $5 \mathrm{mg} / \mathrm{kg}$; bretylium tosylate, 7.5 $10 \mathrm{mg} / \mathrm{kg}$; propranolol hydrochloride, $0.3 \mathrm{mg} / \mathrm{kg}$; and phenoxybenzamine hydrochloride, $10 \mathrm{mg} / \mathrm{kg}$. With the exception of phenoxybenzamine, these agents were administered either intravenously or intra-arterially $\frac{1}{2}-1 \mathrm{~h}$ before the infusion of cyanide. Phenoxybenzamine, diluted in $200-300 \mathrm{ml}$ of normal saline, was infused intravenously over a period of $1 \mathrm{~h}$ and after a second hour had elapsed, cyanide was infused. The doses of these blocking agents are large enough to abolish or greatly reduce the actions of the sympathetic nervous system and the effects of the intravenous administration of catecholamines (11-18). The completeness of blockade produced by the different agents was determined by the following criteria: first, a profound postural hypotension induced by tilting, and a markedly diminished vasopressor response after right common carotid occlusion (the left carotid artery was already ligated and cannulated), second, a markedly diminished vasopressor response after a single intravenous administration of norepinephrine 
(2 $\mu \mathrm{g} / \mathrm{kg})$, and third, the absence of an increase in heart rate after a single intravenous injection of isoproterenol $(0.5 \mu \mathrm{g} / \mathrm{kg})$.

The role of the spleen in the regulation of cardiac output was studied by infusing the standard dose of cyanide into splenectomized dogs with or without propranolol pretreatment. The spleen had been removed via a mid-abdominal incision. Since this operation was associated with surgical trauma and blood loss, the cardiac output response to cyanide infusion was also studied in dogs splenectomized 2 wk previously, as well as in dogs that had had a sham operation or left nephrectomy. The last two groups of animals were also pretreated with propranolol.

Since it had become evident that the spleen was important in the cardiac output response to cyanide infusion, further experiments were designed both to study the role of the splenic nerves in bringing about this particular action of the spleen, and also to demonstrate the existence of a cardioactive substance released from the spleen after the infusion of cyanide. First, in order to study the role of the splenic nerves, the spleen was exteriorized through a midline incision. The splenic artery, including the nerves, and vein were dissected free from the surrounding tissue and any connection remaining between the spleen and the other organs was severed. The spleen was denervated by carefully dissecting and sectioning the nerves adherent to the splenic artery; $1 \%$ phenol and $95 \%$ ethanol were then applied to this area of the artery to ensure complete denervation. The spleen was then put back into the abdominal cavity and the abdomen closed. In addition to splenic denervation, propranolol was administered. Second, in order to investigate the existence of a positive inotropic substance released from the spleen in response to cyanide infusion, splenic venous blood, obtained from donor dogs 2-10 min after the start of cyanide infusion, was infused into the portal vein of recipient dogs at a rate of $1 \mathrm{ml} / \mathrm{kg} / \mathrm{min}$ over 7-8 min, and dye cardiac output was measured in the recipient dogs every 3-5 min. Similar infusion of arterial blood was made in the same dogs to serve as the control.

Statistical analyses. The results obtained were grouped according to the treatments received and the data were analyzed by parametric statistics. Each pool of values was characterized by the mean and the standard error. In each group the control values (obtained before the infusion of cyanide) were reported as the absolute values and the changes occurring after cyanide infusion were expressed as the percentage of the control or as the difference from the control. The significance of these changes within each group was determined by the $t$ test for paired data (19). In addition, the differences among group means were examined by a multiple range test simplified by Kramer (20) in order to evaluate the significance of differences between means. A difference was considered "significant" if the $P$ value was less than 0.05 .

\section{RESULTS}

Hemodynamic and metabolic changes in intact dogs after cyanide infusion

Seven intact dogs were infused intra-aortically with the standard dose of cyanide and the results are shown in Fig. 1 and Tables I-III (group 1). The control cardiac output for each dog was the average of two or three determinations obtained shortly before cyanide infusion. In response to cyanide infusion, cardiac output

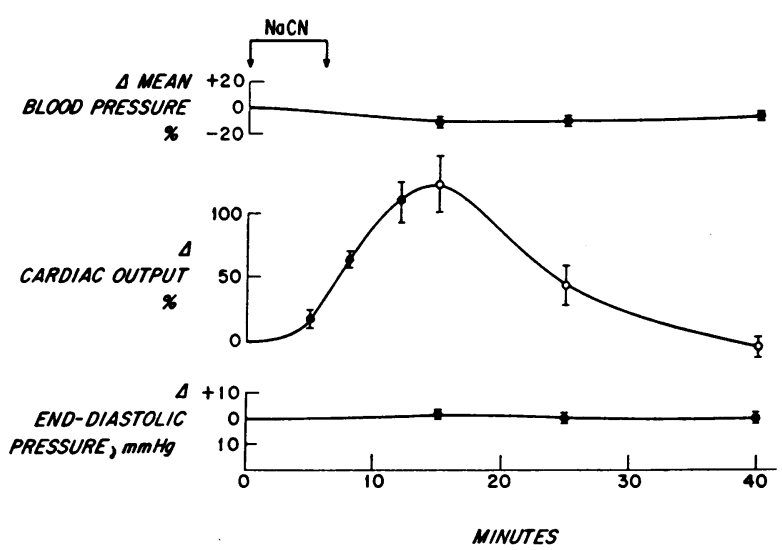

FIGURE 1 Characteristic hemodynamic responses of intact dogs to the intra-aortic infusion of cyanide. Vertical lines indicate the SEM. Both dye (closed circles) and Fick (open circles) cardiac outputs are shown.

began to increase steadily in 3-5 min after the beginning of infusion and in 15 min reached a peak which averaged $221.2 \%$ ( $\mathrm{SEM}, \pm 22.8 \%$ ) of the control value. In $25 \mathrm{~min}$, it fell to $141.8 \%( \pm 14.9 \%)$ of the control and finally returned to control in $40 \mathrm{~min}$. This increase in cardiac output was accompanied by an increase $(27.1 \pm 10.7$ beats/ $\mathrm{min}$ ) in heart rate and a small decrease in mean arterial blood pressure $(\overline{\mathrm{Pa}}) .^{2}$ Right ventricular end-diastolic pressure did not differ significantly from the control, but right ventricular systolic pressure increased in all instances. Blood oxygen capacity increased promptly and stayed elevated after cyanide infusion. Arterial blood $\mathrm{pH}$ did not change.

Cyanide infusion reduced the rate of oxygen consumption and simultaneously increased the ratio of lactate to pyruvate concentrations $(\mathrm{L} / \mathrm{P})$ in the arterial blood. Both metameters reached their maximal changes shortly after the termination of cyanide infusion; these maximal changes are shown in Table II. Thereafter, oxygen consumption returned rapidly to, and even overshot, the control value at the time of the peak cardiac output rise, whereas L/P ratio fell slowly over $1 \mathrm{hr}$.

\section{Role of the vagus nerves and cholinergic receptors}

In five vagotomized dogs, four of which had received atropine pretreatment, cardiac output was $114.9 \pm 8.1 \mathrm{ml} /$ $\mathrm{kg} / \mathrm{min}$. It increased after cyanide infusion to $241.5 \pm$ $25.1 \%, 141.9 \pm 5.8 \%$, and $113.2 \pm 11.1 \%$ of the control at 15,25 , and $40 \mathrm{~min}$, respectively. None of these values differs significantly from those in intact dogs, as determined by Student's $t$ test. Other hemodynamic and meta-

Abbreviations used in this paper: L/P, ratio of lactate to pyruvate concentrations; $\overline{\mathrm{Pa}}$, mean arterial blood pressure. 
TABLE I

Cardiac Output Response to Intra-aortic Cyanide Infusion in Intact Dogs and in Dogs Pretrealed with Agents that Block Sympathetic Nervous System*

\begin{tabular}{lcccc}
\hline & & \multicolumn{3}{c}{ After start of cyanide infusion } \\
\cline { 4 - 5 } \multicolumn{1}{c}{ Group } & Control & $15 \mathrm{~min}$ & $25 \mathrm{~min}$ & $40 \mathrm{~min}$ \\
\hline & $\mathrm{ml} / \mathrm{kg} / \mathrm{min}$ & & $\%$ of control \\
1. Intact $(n=7)$ & $126.1 \pm 7.7$ & $221.2 \pm 22.8 \S$ & $141.8 \pm 14.9 \|$ & $96.2 \pm 7.4$ \\
2. Bret. or mecam. $(n=10)$ & $117.7 \pm 6.6$ & $147.0 \pm 15.9 \|$ & $148.7 \pm 21.6 \|$ & $80.0 \pm 7.6 \|$ \\
3. Propranolol $(n=6)$ & $119.4 \pm 7.1$ & $157.9 \pm 12.7 \S$ & $106.6 \pm 3.3$ & $85.2 \pm 1.79$ \\
4. Prop. + PBZ $(n=7)$ & $134.0 \pm 9.1$ & $184.6 \pm 14.2 \S$ & $150.5 \pm 30.5$ & $101.5 \pm 12.8$ \\
5. Bret. or mecam. + prop. $(n=10)$ & $119.0 \pm 10.8$ & $103.4 \pm 7.7$ & $78.6 \pm 9.9$ & $74.4 \pm 8.7 \|$ \\
Multiple range test $\neq$ & $(1,2,3,4,5)$ & $(1,4)$ & $(1,2,3,4)$ & $(1,2,3,4,5)$ \\
& & $(2,3,4)$ & $(3,5)$ & \\
\end{tabular}

\footnotetext{
* Results are mean \pm SEM. The number of experiments per group is given in parentheses. Abbreviations are as follows: bret., bretylium; mecam., mecamylamine; PBZ, phenoxybenzamine; prop., propranolol. $\ddagger$ The means of any two groups not appearing together within the same parentheses are significantly different at $P<0.05$. The means of any two groups appearing together within the same parentheses are not significantly different.

$\S P<0.01$ for difference from the control.

$\| P<0.05$ for difference from the control.

If $P<0.001$ for difference from the control.
}

bolic measurements made in vagotomized dogs also were not significantly different from those in intact dogs.

\section{Role of the sympathetic nervous system}

The effectiveness of the blocking agents used was đetermined by the criteria listed under Methods. It was found that mecamylamine, bretylium, and phenoxybenzamine produced profound postural hypotension when the animal was tilted and that mecamylamine and phenoxybenzamine greatly reduced the pressor response to common carotid occlusion. Bretylium, in the doses used, failed to diminish the pressor response to carotid occlusion. Phenoxybenzamine greatly reduced the pressor response after administration of norepinephrine, while

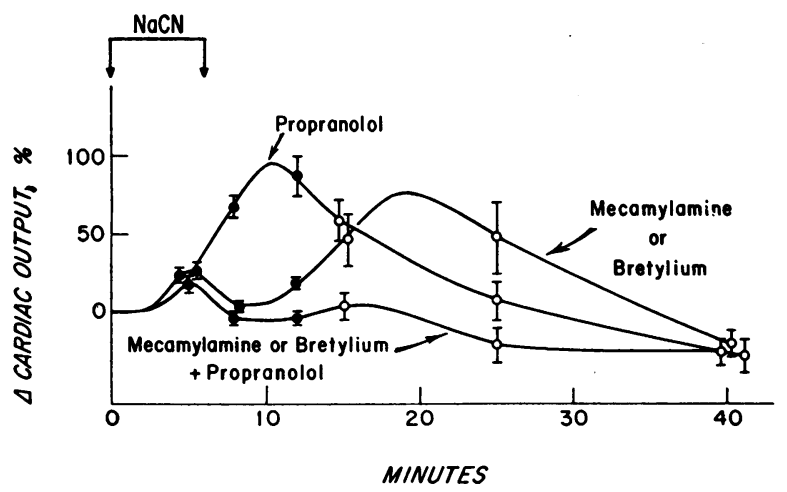

FIGURE 2 Effects of agents that block the sympathetic nervous system on the cardiac output response to the intraaortic infusion of cyanide. propranolol completely abolished the increase in heart rate after administration of isoproterenol. The effects of these blocking agents on the hemodynamic and metabolic responses to cyanide are presented under three categories.

\section{Cardiac Output Response (Fig. 2 and Table I)}

Mecamylamine or bretylium (group 2). When dogs were pretreated with mecamylamine or bretylium, the cardiac output response to cyanide infusion became biphasic. 3-5 min after the start of cyanide infusion, cardiac output increased slightly to $124 \pm 4 \%$ of the control but returned within the next 3 or $4 \mathrm{~min}$ to $103.9 \pm 4.8 \%$ of control values. In 10-15 min, cardiac output began to increase again and at $20 \mathrm{~min}$ was at its peak, about $180 \%$ of the control. At $25 \mathrm{~min}$, cardiac output was still significantly elevated, returning to control levels in $40 \mathrm{~min}$. All dogs in this group showed this biphasic pattern in the cardiac output response to cyanide infusion. This response, then, is characterized by the return of cardiac output to its control value 5-15 min after the start of cyanide infusion, followed by a second rise in cardiac output that returns to control in $40 \mathrm{~min}$.

Propranolol (group 3). The biphasic response observed in group 2 did not occur in animals pretreated with propranolol. Instead, in these animals cardiac output increased similarly to that of the control animals (group 1), but the peak occurred earlier (within $10 \mathrm{~min}$ ) and was of smaller magnitude. Furthermore, cardiac output returned to control values earlier (within $25 \mathrm{~min}$ ) and stabilized at values slightly below control levels. 


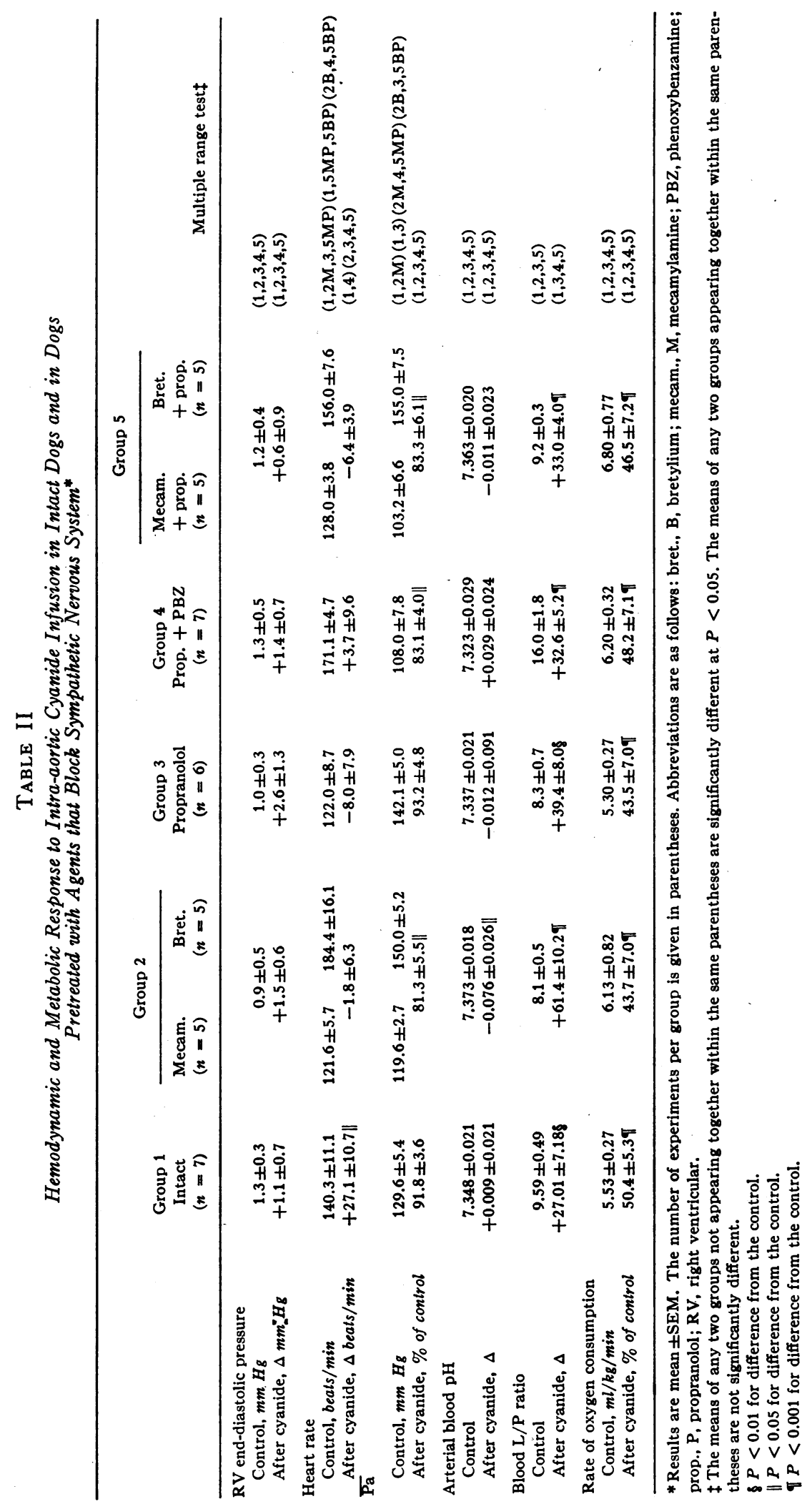

Cardiac Output Regulation in Hypoxia 
Propranolol plus phenoxybenzamine (group 4). The cardiac output response to cyanide infusion in this group was similarly monophasic; the addition of phenoxybenzamine did not alter the cardiac output response significantly.

Propranolol plus mecamylamine or bretylium (group 5 ). When dogs were pretreated with both propranolol and one of the sympatholytic agents (mecamylamine or bretylium), the cardiac output response to cyanide was similar to that observed in animals pretreated with either mecamylamine or bretylium alone (group 2) in that it rose to $118 \pm 5.4 \%$ of the control value in $3-5 \mathrm{~min}$ after the start of cyanide infusion, but different in that it did not rise again; cardiac outputs measured at 15 and 25 min were not significantly different from the control.

\section{Other Hemodynamic Responses (Table II)}

Right ventricular end-diastolic pressure. Right ventricular end-diastolic pressure did not differ significantly among any of the experimental groups before cyanide infusion, and it did not change at the time cardiac output was maximally elevated after cyanide infusion.

$\overline{P a} . \quad \overline{\mathrm{Pa}}$ was not altered by propranolol, but it was changed by other agents. Mecamylamine and phenoxybenzamine decreased the pressure, while bretylium increased it. However, these changes in $\overline{\mathrm{Pa}}$ did not affect the control cardiac output, nor did they alter the $\overline{\mathrm{Pa}}$ response to cyanide infusion. In response to cyanide infusion, $\overline{\mathrm{Pa}}$

TABLE III

Changes in Blood Oxygen Capacity in Intact and Drugpretreated Dogs after Intra-aortic Cyanide Infusion*

\begin{tabular}{cc}
\hline Group & Oxygen capacity \\
\hline & $m l /$ liter \\
1. Intact $(n=7)$ & $+45.3 \pm 9.8 \S$ \\
2. Bret. $(n=5)$ & $-2.0 \pm 2.8$ \\
Mecam. $(n=5)$ & $+37.3 \pm 7.2 \S$ \\
3. Prop. $(n=6)$ & $+29.6 \pm 2.79$ \\
4. Prop. + PBZ $(n=6)$ & $+0.6 \pm 3.1$ \\
5. Bret. + prop. $(n=5)$ & $+3.7 \pm 1.8$ \\
Mecam. + prop. $(n=5)$ & $+27.7 \pm 7.4 \|$ \\
Multiple range testł: $(1,2 \mathrm{M}, 3,5 \mathrm{MP}),(2 \mathrm{~B}, 4,5 \mathrm{BP})$ \\
\hline
\end{tabular}

* Results are mean $\pm \mathrm{SEM}$. The number of experiments per group is given in parentheses. Abbreviations are as follows: bret., B, bretylium; mecam., M, mecamylamine; PBZ, phenoxybenzamine; prop., $\mathrm{P}$, propranolol.

$\ddagger$ The means of any two groups not appearing together within the same parentheses are significantly different at $P<0.05$.

The means of any two groups appearing together within the same parentheses are not significantly different.

$\S P<0.01$ for difference from the control.

$\| P<0.05$ for difference from the control.

II $P<0.001$ for difference from the control. dropped to $80-90 \%$ of the control in 3-5 $\mathrm{min}$; this change in $\overline{\mathrm{Pa}}$ was associated with a small concurrent increase in cardiac output. During the subsequent course after cyanide infusion, $\overline{\mathrm{Pa}}$ stayed at this low level in all groups of animals regardless of changes in cardiac output.

Heart rate. Heart rate was not changed by mecamylamine, but it was reduced by propranolol and increased by both phenoxybenzamine and bretylium. It also did not change significantly after cyanide infusion in any of the four experimental groups of drug-pretreated animals.

\section{Metabolic Responses (Tables II and III)}

Arterial blood $\mathrm{pH}$. The blood $\mathrm{pH}$ in dogs of groups 3 and 4 was constant or slightly increased after cyanide infusion, as in intact dogs. In groups 2 and 5 the blood $\mathrm{pH}$ fell slightly. The differences among groups were not statistically significant.

Blood $L / P$ ratio. $\mathrm{L} / \mathrm{P}$ ratios obtained before cyanide infusion in groups $1,2,3$, and 5 were similar; those in group 4 were higher. During cyanide infusion, the L/P ratio rose steadily in all five groups and peaked shortly after the end of infusion. The magnitude of the peak increase in $\mathrm{L} / \mathrm{P}$ ratio in group 2 was higher than in the others, in which the increases were similar.

Rate of oxygen consumption. The blocking agents used did not affect the rate of oxygen consumption during control or after cyanide infusion.

Blood oxygen capacity. The usual increase in blood oxygen capacity seen in intact animals after the infusion of cyanide was abolished by phenoxybenzamine and bretylium, but not by propranolol or mecamylamine.

\section{Role of the spleen}

Fig. 3 and Table IV show that, in contrast to the smooth cardiac output response observed in intact dogs,

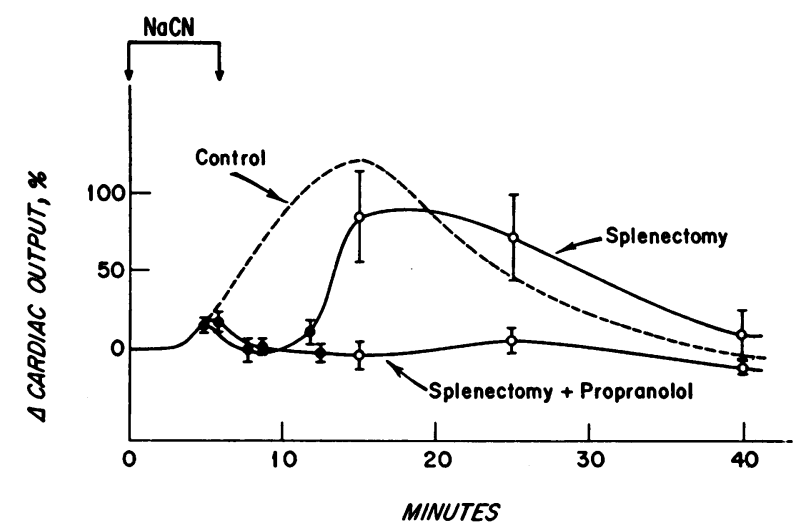

Figure 3 Effects of acute splenectomy and its combination with propranolol on the cardiac output response to the intra-aortic infusion of cyanide. 
TABLE IV

Cardiac Output Response to Intra-aortic Cyanide Infusion*

\begin{tabular}{lcccc}
\hline & & \multicolumn{2}{c}{ After start of cyanide infusion } \\
\cline { 3 - 5 } Group & Control & 15 min & 25 min & 40 min \\
\hline & $m l / k g / m i n$ & & $\%$ of control \\
Sham op. (or nephr.) + propranolol $(n=7)$ & $122.4 \pm 16.0$ & $169.1 \pm 12.8 \ddagger$ & $117.4 \pm 13.9$ & $77.7 \pm 6.0 \ddagger$ \\
Acute splenectomy $(n=9)$ & $123.3 \pm 11.0$ & $185.5 \pm 28.5 \S$ & $172.2 \pm 26.6 \S$ & $109.3 \pm 16.1$ \\
Acute splenectomy + propranolol $(n=16)$ & $92.1 \pm 4.8$ & $95.6 \pm 7.4$ & $105.6 \pm 7.3$ & $87.6 \pm 4.1 \ddagger$ \\
Chronic splenectomy + propranolol $(n=5)$ & $104.9 \pm 9.0$ & $93.8 \pm 4.8$ & $92.8 \pm 13.5$ & $89.0 \pm 12.7$ \\
Splenic denervation + propranolol $(n=4)$ & $132.1 \pm 16.6$ & $79.4 \pm 8.0$ & $101.6 \pm 11.6$ & $76.6 \pm 13.7$ \\
\hline
\end{tabular}

* Results are mean \pm SEM. The number of experiments per group is given in parentheses. Abbreviations are as follows: nephr., nephrectomy; sham op., sham operation.

$\ddagger P<0.01$ for difference from the control.

$\S P<0.05$ for difference from the control.

two smaller peak increases in cardiac output occurred in splenectomized dogs after cyanide infusion. This biphasic pattern of the cardiac output response was similar to that which occurred in dogs pretreated with mecamylamine or bretylium (Fig. 2). The two peaks occurred in 3-5 min and $20 \mathrm{~min}$, respectively, after the start of cyanide infusion. The second peak was abolished by propranolol. Similar changes in cardiac output occurred in dogs splenectomized 2 wk previously (referred to below as chronic splenectomy dogs), but not in sham-operated or nephrectomized dogs (Table IV).

Changes in other hemodynamic and metabolic metameters are shown in Tables $\mathrm{V}$ and VI. The five groups included in the tables are animals with sham operation or nephrectomy plus propranolol, acute splenectomy, acute splenectomy plus propranolol, chronic splenectomy plus propranolol, and splenic denervation plus propranolol. The results in the first group in response to cyanide infusion are not significantly different from those. in animals pretreated with propranolol alone.

Dogs with splenectomies with or without propranolol all showed the following changes after cyanide infusion: $\overline{\mathrm{Pa}}$ was reduced to approximately $80 \%$ of the control, $\mathrm{L} / \mathrm{P}$ ratio was greatly increased, and rate of oxygen consumption was reduced to $45 \%$ or less of the control, but right ventricular end-diastolic pressure, arterial

TABLE V

Hemodynamic and Metabolic Responses to Intra-Aortic Cyanide Infusion in Dogs*

\begin{tabular}{|c|c|c|c|c|c|}
\hline & $\begin{array}{l}\text { Sham op. or nephr. } \\
+ \text { propranolol } \\
(n=7)\end{array}$ & $\begin{array}{c}\text { Acute } \\
\text { splenectomy } \\
(n=9)\end{array}$ & $\begin{array}{c}\text { Acute } \\
\text { splenectomy } \\
+ \text { propranolol } \\
(n=16)\end{array}$ & $\begin{array}{c}\text { Chronic } \\
\text { splenectomy } \\
+ \text { propranolol } \\
(n=5)\end{array}$ & $\begin{array}{c}\text { Splenic } \\
\text { denervation } \\
+ \text { propranolol } \\
(n=4)\end{array}$ \\
\hline \multicolumn{6}{|l|}{$\mathbf{R V}$ end-diastolic pressure } \\
\hline Control, $m \boldsymbol{m ~ H g}$ & $1.4 \pm 0.5$ & $1.4 \pm 0.4$ & $1.4 \pm 0.3$ & $2.4 \pm 0.4$ & $1.3 \pm 0.6$ \\
\hline After cyanide, $\Delta m m \mathbf{H g}$ & $+1.3 \pm 0.5$ & $+1.5 \pm 0.9$ & $+1.4 \pm 0.8$ & $+1.0 \pm 0.7$ & $+2.3 \pm 1.7$ \\
\hline \multicolumn{6}{|l|}{ Heart rate } \\
\hline Control, beats/min & $118.3 \pm 7.5$ & $135.6 \pm 8.0$ & $121.5 \pm 6.0$ & $129.6 \pm 6.3$ & $141.5 \pm 12.5$ \\
\hline After cyanide, $\Delta$ beats $/ \min$ & $+10.6 \pm 10.8$ & $+25.0 \pm 7.2 \ddagger$ & $+1.0 \pm 5.6$ & $-3.2 \pm 3.7$ & $-21.5 \pm 4.7 \ddagger$ \\
\hline \multicolumn{6}{|l|}{$\overline{\mathrm{Pa}}$} \\
\hline Control, $m m \mathrm{Hg}$ & $131.5 \pm 5.0$ & $136.9 \pm 6.7$ & $145.0 \pm 5.0$ & $153.4 \pm 7.8$ & $120.2 \pm 9.7$ \\
\hline After cyanide, $\%$ of control & $94.3 \pm 3.0$ & $74.6 \pm 5.1 \S$ & $78.4 \pm 4.3 \|$ & $71.6 \pm 4.68$ & $83.0 \pm 7.1$ \\
\hline \multicolumn{6}{|l|}{ Arterial blood $\mathrm{pH}$} \\
\hline Control & $7.326 \pm 0.014$ & $7.341 \pm 0.020$ & $7.321 \pm 0.013$ & $7.320 \pm 0.074$ & $7.350 \pm 0.013$ \\
\hline After cyanide, $\Delta$ & $+0.050 \pm 0.020$ & $-0.052 \pm 0.033$ & $-0.038 \pm 0.026$ & $+0.036 \pm 0.046$ & $-0.122 \pm 0.055$ \\
\hline \multicolumn{6}{|l|}{ Blood $L / P$ ratio } \\
\hline Control & $8.5 \pm 0.5$ & $8.9 \pm 0.5$ & $8.1 \pm 0.4$ & $7.4 \pm 0.4$ & $7.9 \pm 0.7$ \\
\hline After cyanide, $\Delta$ & $+16.9 \pm 4.0 \|$ & $+72.5 \pm 16.8 \ddagger$ & $+65.6 \pm 14.0 \|$ & $+52.6 \pm 7.5 \ddagger$ & $+120.5 \pm 33.4 \ddagger$ \\
\hline \multicolumn{6}{|l|}{ Rate oxygen consumption } \\
\hline Control, $\mathrm{ml} / \mathrm{kg} / \mathrm{min}$ & $5.46 \pm 0.19$ & $5.52 \pm 0.37$ & $5.19 \pm 0.21$ & $5.74 \pm 0.43$ & $5.14 \pm 0.55$ \\
\hline After cyanide, $\%$ of control & $47.0 \pm 5.0 \|$ & $44.8 \pm 6.0 \|$ & $41.1 \pm 2.8 \|$ & $35.4 \pm 2.4 \|$ & $27.3 \pm 1.7 \|$ \\
\hline
\end{tabular}

* Results are mean \pm SEM. The number of experiments per group is given in parentheses. Abbreviations are as follows: nephr., nephrectomy; sham op., sham operation; $R V$, right ventricular.

$\ddagger P<0.01$ for difference from the control.

$\& P<0.05$ for difference from the control.

$\| P<0.001$ for difference from the control. 
TABLE VI

Changes in Blood Oxygen Capacity in Dogs after Intra-aortic Cyanide Infusion*

\begin{tabular}{|c|c|}
\hline Group & $\Delta$ oxygen capacity \\
\hline \multirow{2}{*}{\multicolumn{2}{|c|}{ Sham op. (or nephrectomy) }} \\
\hline & \\
\hline+ propranolol $(n=7)$ & $+27.6 \pm 1.4 \S$ \\
\hline Acute splenectomy $(n=9)$ & $+3.3 \pm 3.4$ \\
\hline \multicolumn{2}{|l|}{ Acute splenectomy } \\
\hline+ propranolol $(n=16)$ & $+2.3 \pm 2.7$ \\
\hline \multicolumn{2}{|l|}{ Chronic splenectomy } \\
\hline+ propranolol $(n=5)$ & $+5.9 \pm 2.2$ \\
\hline \multicolumn{2}{|l|}{ Splenic denervation } \\
\hline+ propranolol $(n=4)$ & $+25.4 \pm 8.5 \ddagger$ \\
\hline
\end{tabular}

* Results are mean $\pm \mathrm{SEM}$. The number of experiments per group is given in parentheses. Abbreviation is as follows: sham op., sham operation.

$\ddagger P<0.01$ for difference from the control.

$\S P<0.001$ for difference from the control.

blood $\mathrm{pH}$, and blood oxygen capacity did not change significantly. On the other hand, changes in heart rate differed among these three groups of animals; all splenectomized dogs without propranolol responded to cyanide infusion, as did intact dogs, with an increase in heart rate, but this increase in heart rate was abolished by the addition of propranolol.

In the dogs with splenic denervation plus propranolol pretreatment cardiac output did not increase after cyanide infusion (Table IV) as it did in intact dogs. The cardiac output response to cyanide in these dogs was like that observed in splenectomized dogs pretreated with propranolol and in dogs pretreated with mecamylamine (or bretylium) plus propranolol. In addition, changes in right ventricular end-diastolic pressure, $\overline{\mathrm{Pa}}$, heart rate, rate of oxygen consumption, $\mathrm{L} / \mathrm{P}$ ratio, and blood $\mathrm{pH}$ were the same in these three groups of animals. However, blood oxygen capacity increased significantly in splenically denervated and mecamylamine-pretreated dogs, but not in the splenectomized or bretylium-pretreated animals.

Table VII shows that cardiac output increased after intraportal infusion of the splenic venous blood obtained from dogs infused with cyanide. This increase in cardiac output was accompanied by a slight increase in $\overline{\mathrm{Pa}}$, but heart rate and right ventricular end-diastolic pressure remained unchanged. Similar infusion of arterial blood produced only a small increase in cardiac output. Paired comparison analyses indicate that infusion of both arterial blood and splenic venous blood increased cardiac output, and that the mean differences in pre- and postinfusion cardiac outputs were significantly different after both kinds of infusion. The mean percent increase was higher after the infusion of the splenic venous blood $(t=3.77, \mathrm{df}=11, P<0.005)$. However, since control cardiac outputs varied from animal to animal and from experimental infusion to experimental infusion, it was difficult to determine the biological and statistical significance of the changes in cardiac output produced by infusion of both kinds of blood. Hence we attempted to determine the difference between predicted values of cardiac output after infusion of both kinds of blood when the control cardiac output was kept constant statistically. For both kinds of infusion, the postinfusion cardiac output was found to be related linearly to the control cardiac output. The line of best fit for data obtained for both kinds of infusion was fitted by the method of least

TABLE VII

Changes in Cardiac Output after Intraportal Infusion of Splenic Venous and Arterial Blood in Dogs

\begin{tabular}{|c|c|c|c|c|c|c|}
\hline \multirow[b]{2}{*}{ Body weight } & \multicolumn{3}{|c|}{ Splenic venous blood } & \multicolumn{3}{|c|}{ Arterial blood } \\
\hline & Control & $\begin{array}{c}\text { After } \\
\text { infusion }\end{array}$ & Change & Control & $\begin{array}{c}\text { After } \\
\text { infusion }\end{array}$ & Change \\
\hline $\mathrm{kg}$ & \multicolumn{2}{|c|}{ liter/min } & $\%$ & \multicolumn{2}{|c|}{ liter/min } & $\%$ \\
\hline 19.0 & 1.08 & 1.30 & +20.4 & 1.13 & 1.30 & +15.0 \\
\hline 20.0 & 1.51 & 1.97 & +30.5 & 1.75 & 1.91 & +9.3 \\
\hline 14.0 & 1.81 & 2.60 & +43.6 & 1.87 & 1.90 & +1.6 \\
\hline 16.5 & 2.43 & 3.80 & +56.4 & 2.12 & 2.41 & +13.7 \\
\hline 20.0 & 2.65 & 4.21 & +58.9 & 3.61 & 3.85 & +6.6 \\
\hline 30.0 & 2.80 & 5.41 & +93.2 & ND & ND & ND \\
\hline 26.5 & 2.91 & 3.50 & +20.2 & 3.79 & 3.76 & -0.8 \\
\hline Mean & 2.17 & 3.26 & +46.2 & 2.38 & 2.52 & +7.6 \\
\hline SEM & 0.27 & 0.53 & 9.9 & 0.44 & 0.43 & 2.6 \\
\hline
\end{tabular}

ND, not determined. 
squares (Fig. 4), and the predicted cardiac outputs were found by interpolating at a value for the control cardiac output corresponding to the arithmetic mean of all control cardiac outputs for the two series, i.e., 2.275 liters/ min. The significance of the difference between these two predicted cardiac outputs was determined with Student's $t$ test. The predicted value for cardiac output after splenic venous blood infusion was $3.44 \pm 0.26 \mathrm{liter} / \mathrm{min}$, while after arterial blood infusion it was $2.42 \pm 0.18$ liter/min; the difference between these two sets of values is significant at the 0.005 level $(t=3.866$, df $=$ 11). Therefore, we could infer that if all animals in all experiments had had the same mean control cardiac output, the infusion of splenic venous blood would have produced an increase in cardiac output significantly higher than that predicted to be produced by the infusion of arterial blood under identical conditions.

\section{DISCUSSION}

Cyanide specifically inhibits cytochrome oxidase $(21,22)$. At concentrations as low as $10^{-6}$ to $10^{-8} \mathrm{M}$, it produces $50 \%$ inhibition of cytochrome oxidase in most tissues, whereas concentrations $10^{2}$ to $10^{\circ}$ times greater are necessary to achieve $50 \%$ inhibition of other enzymes (22). In the experiments reported here, if all the cyanide infused $(0.03 \mathrm{mmol} / \mathrm{kg})$ had been retained in the abdomen and hindlimbs of the dog in a volume of distribution approximating $40 \%$ of body weight, and if none were inactivated, the concentration of hydrocyanic acid in the tissues would appear to be too low to produce any significant effect on any enzymes other than cytochrome oxidase. That cyanide inhibited cytochrome oxidase in these experiments was inferred from the reduction in rate of oxygen consumption and the increase in blood $\mathrm{L} / \mathrm{P}$ ratio (Tables II and $\mathrm{V}$ ). Thus, it may be concluded that cyanide infusion did alter the oxidation-reduction state of the cytochrome system toward the reduced state.

The predicted pharmacological actions of mecamylamine, propranolol, and phenoxybenzamine were produced by the doses used, as judged by the criteria described under Methods. Bretylium, in the doses used, did not diminish the pressor response to common carotid occlusion, as Aviado and Dil (15) and Ledsome and Linden (17) also found. However, since we found that these doses of bretylium were large enough to produce marked postural hypotension, and because they are sufficient to block the actions of cardiac nerve stimulation (15-17) and of splenic nerve stimulation (14), we can conclude that these doses of bretylium produced sympathetic blockade.

Table I and Fig. 2 show that the rise in cardiac output after cyanide infusion was markedly diminished by agents that inactivate the sympathoadrenal system, but it was not affected significantly by vagotomy or cholinergic

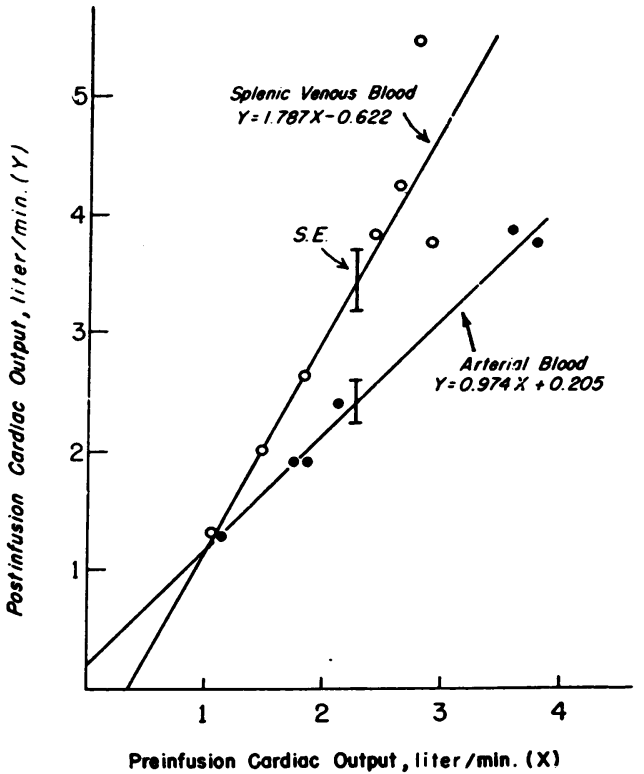

FIgURE 4 Changes in cardiac output after the intraportal infusion of arterial and splenic venous blood.

receptor blockade. In contrast to the large prolonged increase in cardiac output seen in intact dogs after cyanide infusion (Fig. 1), in the dogs pretreated with both mecamylamine (or bretylium) and propranolol cardiac output increased only slightly 3-5 min after the start of cyanide infusion (early phase). The major portion of the rise in cardiac output in intact dogs after cyanide infusion could be abolished, then, by the simultaneous administration of a sympatholytic agent and a beta-adrenergic receptor blocker. The remaining increase in cardiac output after cyanide infusion in these drug-pretreated dogs depends neither on the functional integrity of the sympathetic nerves nor on the activities of betaadrenergic receptors. The observation that $\overline{\mathrm{Pa}}$ fell as cardiac output rose in these animals might support that the rise in cardiac output resulted from decreased aortic impedance. However, no further data exist at this moment to substantiate this or explain adequately the mechanism responsible for the increased cardiac output.

It is also shown in Fig. 2 and Table I that the cardiac output response to cyanide infusion in animals with sympathetic blockade produced by mecamylamine or bretylium is different from that in animals with betaadrenergic receptor blockade produced by propranolol. Mecamylamine (or bretylium) abolished the middle phase of the cardiac output rise, beginning at $5 \mathrm{~min}$ and ending at $25 \mathrm{~min}$ after the start of cyanide infusion, while propranolol diminished the late phase beginning at $15 \mathrm{~min}$ and ending at $40 \mathrm{~min}$ after the start of cyanide infusion. Therefore, it seems unlikely that the rise in

Cardiac Output Regulation in Hypoxia 3123 
cardiac output during the middle phase results from actions on the heart, either of the cardiac sympathetic nerves or of circulating catecholamines, both of which act via beta-adrenergic receptors. Furthermore, since the increased cardiac output during the middle phase was not altered by phenoxybenzamine and propranolol together, it would appear that this rise in cardiac output is mediated by sympathetic nerves that activate neither alpha- nor beta-adrenergic receptors.

The absence of the middle phase of the cardiac output rise after cyanide infusion in the drug-pretreated dogs might result from direct depressant effects of cyanide or acidosis on the myocardium or both. This seems unlikely, however, since the changes in arterial blood $\mathrm{pH}$ after cyanide infusion were not significantly different among the groups (Table II). Furthermore, it has been shown previously by one of us ${ }^{1}$ that in intact dogs the amount of cyanide in the right or left ventricular blood is insufficient to depress myocardial function after the intraaortic infusion of cyanide $(0.04 \mathrm{mmol} / \mathrm{kg}$ in $5 \mathrm{~min})$, and that even if cyanide does reach the heart, when the same amount of cyanide is infused intravenously, cardiac output is not decreased and may even increase. It would appear, then, that myocardial contractility was not depressed by the amount of cyanide given intra-aortically in these dogs.

The middle phase of the cardiac output rise after cyanide infusion also was abolished by both splenectomy and splenic denervation (Fig. 3). This effect was not related to the surgical procedure or to the blood loss since it was still evident in the chronic splenectomy dogs and operations comparable to splenectomy (i.e., sham operation and nephrectomy) did not prevent the cardiac output from increasing during the middle phase after cyanide infusion (Table IV). It probably was also not due to the loss of a blood volume that the spleen could eject into the general circulation upon contraction. Several investigators (23-25) have shown that splenic contraction increases the total blood volume by only $6-15 \%$. From the results in Table VII, it is evident that the intraportal infusion of a volume of arterial blood approximating $10 \%$ of the total blood volume $(7-8 \mathrm{ml} / \mathrm{kg})$ produced only a small increase in cardiac output.

Tables II and $\mathrm{V}$ show that changes in right ventricular end-diastolic pressure and $\overline{\mathrm{Pa}}$ after cyanide infusion were the same in all groups of dogs, regardless of changes in cardiac output. Thus, it appears likely that the increase in cardiac output in the middle phase after cyanide infusion is not mediated by either the Frank-Starling mechanism or aortic impedance, and that it may be brought about by the inotropic action of a humoral substance from the spleen by sympathetic stimulation. This possibility is further suggested by the demonstration that the intraportal infusion of splenic venous blood from cyanide-treated dogs increased the cardiac output in intact dogs. In contrast, the same amount of arterial blood increased cardiac output only slightly when it was infused intraportally. Therefore, this effect of the splenic venous blood is not due to the blood volume expansion produced by blood transfusion; instead, it is most likely caused by the inotropic action of a humoral substance present in the splenic venous blood.

We have demonstrated recently that cardiac output can be increased by sympathetic stimulation of the spleen (2). An inotropic substance in the splenic venous blood was first postulated by Rein et al. (3). They found that cardiac function in a heart-lung preparation deteriorated spontaneously, but that if the liver and spleen were included in the heart-lung preparation, splenic nerve stimulation would improve the function of the failing heart. Furthermore, Rein and Bohrn (4) showed that the splenectomized dog tolerates coronary occlusion poorly, and that splenic venous blood obtained from a normal dog, when administered transhepatically to the splenectomized dog, overcomes to a considerable degree the functional deterioration of the heart produced by occlusion. This action of the splenic venous blood clearly is not due to blood volume expansion, since the transfusion of the same volume of arterial blood did not result in any improvement of cardiac function in the same preparation. Therefore, Rein and his associates postulated that cardiac anoxia causes an unknown substance to be released from the spleen by nerve stimulation, and that, because this substance must enter the hepatic circulation, it is modified in the liver before it can exert its action on the heart to improve myocardial function. Subsequently, Meesmann and Schmier (26-28) not only confirmed those findings, they also showed that splenic nerve stimulation increases the efficiency of cardiac energy utilization.

The spleen contains abundant amounts of norepinephrine and epinephrine that are released by sympathetic nerve stimulation (29-31), but it is unlikely that either of these substances is responsible for the effects on cardiac output, since they do not increase cardiac output when infused intraportally $(2,3,32)$. We have shown in both these experiments and others (2) that this action of the spleen is not abolished by propranolol, which further minimizes the possible role of catecholamines. Besides catecholamines, prostaglandins are found in the spleen and are released into the blood stream after splenic nerve stimulation $(33,34)$. However, since prostaglandins, when infused into the portal vein, are largely inactivated in the liver, and little of them reaches the heart to produce any significant effect (35), it seems unlikely that prostaglandins are responsible for the increased cardiac output after splenic nerve stimulation.

Recently, Cobbin and Thorp (36) found that the acetone fraction of splenic extracts contains a cardio- 
active material that produces a positive inotropic action on the papillary muscle of the cat and on the isolated Langendorff heart of the guinea pig. Thorp has succeeded in purifying this cardioactive substance and named it "splenitransin" because it is plentiful in the spleen and acts on a distant organ, the heart (37). However, there are no data to indicate whether splenitransin is identical with Rein's substance released from the spleen on stimulation of the splenic nerves and found in splenic venous blood, nor is it known whether this splenic substance has any physiological function. Therefore, at the present time, there are no data to help identify the chemical nature of the splenic substance released by sympathetic nerve stimulation after the infusion of cyanide.

Since, as mentioned previously, the late phase of the cardiac output rise after cyanide infusion was abolished by propranolol but not by mecamylamine (or bretylium), this rise in cardiac output probably is caused by the action of circulating catecholamines on cardiac betaadrenergic receptors. An increase in plasma catecholamine concentration after cyanide infusion is further suggested by the finding that splenic denervation, produced by either mecamylamine (Table III) or surgery (Table VI), did not prevent the spleen from contracting (an alpha-adrenergic effect) in response to cyanide infusion. That the spleen contracted may be inferred from the increase in blood oxygen capacity, presumably associated with the discharge of erythrocytes from the spleen upon contraction (38). Oxygen capacity did not increase in the bretylium-pretreated dogs (Table III). The spleen had been stimulated once already by the initial sympathomimetic actions of bretylium and, therefore, could not discharge a significant number of erythrocytes when stimulated a second time after cyanide infusion. However, our experiments do not provide sufficient information to permit us to identify either the source from which, or the mechanism by which, catecholamines are released into the general circulation after cyanide infusion.

The adrenal medulla, the largest chromaffin tissue in the body, might be the source of the catecholamines that increase cardiac output during the late phase of the cardiac output response to cyanide infusion. The adrenal medulla can secrete catecholamines upon either nervous or humoral stimulation $(39-41)$. The nervous mechanism is usually considered to be the more important one ; Cannon, Linton, and Linton (42) showed in exercising dogs that catecholamines were not released from the adrenal medulla when the gland was denervated. Furthermore, they showed that catecholamines also were not released when the venous flow from exercising limbs was occluded from the general circulation. Therefore, the release of catecholamines from the adrenal medulla during exercise appears to be brought about by stimulation of the preganglionic fibers to the adrenal medulla in response to a humoral substance, which is produced in hypoxic tissues and must enter the general circulation to initiate catecholamine release. This humoral substance probably is an anaerobic tissue metabolite. However, since mecamylamine did not block the increase in cardiac output that occurred in the late phase after cyanide infusion, it is possible that catecholamines are released from the adrenal medulla by direct actions of anaerobic tissue metabolites, such as those demonstrated by Bülbring, Burn, and De Elio (39) and Rubin (41).

Tables II and V show that when cardiac output was prevented from rising during the middle phase after cyanide infusion by chemical sympathectomy, splenectomy, or splenic denervation, the blood $\mathrm{L} / \mathrm{P}$ ratio rose to values greater than those in intact dogs. Since it has been shown that cyanide toxicity is lessened by oxygen administration (43), an increase in cardiac output, which increases oxygen delivery to tissues, probably could overcome to a considerable degree the inhibitory action of cyanide on tissue metabolism. Cyanide should exert a greater action on tissue metabolism when cardiac output fails to increase. However, this does not explain why the same high rises in $L / P$ ratio did not occur in dogs pretreated with mecamylamine (or bretylium) plus propranolol (Table II), although they, too, lacked the middle phase of the cardiac output rise after cyanide infusion.

In conclusion, the cardiac output response to cyanide infusion can be characterized by an early, a middle, and a late phase. The mechanism for the increase in cardiac output seen in the early phase is not clearly understood; however, it involves neither the sympathetic nerves nor the adrenergic receptors. The increase in cardiac output seen in the middle phase probably is caused by a nonadrenergic substance released from the spleen by sympathetic stimulation, whereas the increase in cardiac output seen in the late phase is most likely brought about by the direct actions of circulating catecholamines on the heart.

These experimental results are consistent with those of Korner and White (44), who found that the increased cardiac output during respiratory hypoxemia in rabbits was markedly diminished by adrenalectomy and guanethidine-induced sympathectomy. Similarly, Ashkar and Hamilton (45) found that the animals' capacity to increase cardiac output during moderate and severe exercise was markedly reduced when both adrenal medullae and sympathetic chains were removed surgically. In both studies it also was observed that neither sympathectomy nor adrenalectomy alone impaired the animals' capacity to increase cardiac output during exercise and hypoxemia, but no triphasic responses like those we described above for cyanide infusion were observed. The mechanism of action of the adrenal medulla is most 
likely mediated via the inotropic action of its neurohumor -epinephrine-on the heart; that of sympathetic nerves is more complex. If this effect of sympathetic nerves also were mediated through the actions of catecholamines on the heart, we would expect a beta-adrenergic receptor blocking agent to block the actions of both the adrenal medulla and the sympathetic nerves. Several investigators have studied cardiac performance during hypoxemia and exercise in human subjects and in dogs pretreated with beta-adrenergic receptor blocking agents and found that during mild and moderate hypoxia, the increase in cardiac output was not altered significantly $(46-48)$. Therefore, as was true for cyanide infusion, this effect of sympathetic nerves during exercise and hypoxemia probably is not mediated through the actions of catecholamines on the heart. In order to determine which sympathetic nerves are involved in bringing about the increase in cardiac output, Ashkar, Stevens, and Houssay carried out experiments in which they removed different sympathetic nerves (49-51). Like Donald and Shepherd (52), they found that the cardiac nerves do not play an important role in this respect. They further found that the hepatomesenteric nerves control the cardiac output response to exercise, but the mechanism by which these nerves act to increase cardiac output is still unknown. If the cardiac output controlling mechanisms are indeed similar in exercise and in the cyanide model of tissue hypoxia, we can speculate that the hepatomesenteric nerves act to increase cardiac output by releasing an inotropic substance from the spleen.

The physiological function of the spleen has never been studied extensively in relation to the cardiovascular function. Several studies indicate that splenectomized dogs are less resistant to the development of carbon monoxide poisoning (53) and shock $(54,55)$, which usually is explained by the removal of the intrasplenic volume of blood which normally is discharged from the spleen into the general circulation under these conditions. However, other actions of the spleen, including the inotropic agent discussed above, should be considered.

In man, unlike dogs, the spleen is not considered to be a large blood reservoir; hence, people who have been splenectomized are ideal subjects in whom to study other physiological functions of the spleen. Ask-Upmark (56) first studied 100 Swedish men and women whose spleens had been removed because of trauma. These people were studied, on an average, $8 \mathrm{yr}$ after their operations. The most commonly recorded symptoms were fatigue, lack of physical endurance, and anginoid pain in the chest. Some patients had had to change to easier jobs. These findings were confirmed by other investigators (57-61) ; the incidences of these complaints varied from 10 to over $50 \%$ of the people surveyed. In addition, Focke (62) and Hermanuz and Westerberg (63) showed that some splenectomized patients had pathological changes in their electrocardiograms. However, the significance of these changes is difficult to assess because reliable information about the incidences of these changes in a normal population of people who have had other operative procedures comparable to splenectomy is not available. It is also complicated by the long interval between operation and follow-up; some symptoms may have disappeared or been forgotten by the patients. Nevertheless, these findings do indicate that splenectomized persons may have some cardiac dysfunction that might be related to the loss of the spleen. The real significance of this organ in our daily activities warrants further studies.

\section{ACKNOWLEDGMENTS}

The authors express their gratitude to Drs. Vincent Lanzoni, Edward W. Pelikan, Irving Page, William B. Hood, Jr., and J. Worth Estes for much valuable advice, and to Adele Rymut, Joan Luthy, and Janet Snader for their excellent technical assistance.

This research was supported in part by Public Health Service Research Grant HL-06297 and Program Project Grant HE-07299.

The following chemicals were generously supplied by pharmaceutical companies: Mecamylamine $\mathrm{HCl}$ (Inversine) by Merck Sharp and Dohme, Inc., Div. of Merck \& Co., Inc., West Point, Pa., bretylium tosylate (Darenthin) by Burroughs Wellcome \& Co., Inc., Tuckahoe, N. Y., propranolol $\mathrm{HCl}$ (Inderal) by Ayerst Laboratories, Div. of American Home Products Corp., New York, phenoxybenzamine $\mathrm{HCl}$ (dibenzyline) by Smith, Kline \& French Laboratories, Philadelphia, $\mathrm{Pa}$., and indocyanine green (Cardio-Green) by Hynson, Westcott \& Dunning, Inc., Baltimore, Md.

\section{REFERENCES}

1. Rushmer, R. F. 1962. Effects of nerve stimulation and hormones on the heart; the role of the heart in general circulatory regulation. Handb. Physiol. Section 2, Circulation. 533.

2. Liang, C., and W. E. Huckabee. 1973. Effects of sympathetic stimulation of the spleen on cardiac output. Am. J. Physiol. 224 : 1099.

3. Rein, H., O. Mertens, and E. Bücherl. 1949. Über ein Regulationssystem "Milz-Leber" für den oxydativen Stoffwechsel der Körpergewebe und besonders des Herzens. Naturwissenschaften. 36: 233.

4. Rein, H., and A. Bohrn. 1951. Die Beeinflussung von Coronar- oder Hypoxie-bedingten Myokard-Insuffizienzen durch Milz und Leber. Pflügers Arch. Gesamte Physiol. Menschen Tiere. 253: 435.

5. Ramsey, L. H. 1959. Analysis of gas in biological fluids by gas chromatography. Science (Wash. D. C.). 129: 900.

6. Van Slyke, D. D., and J. M. Neill. 1924. The determination of gases in blood and other solutions by vacuum extraction and manometric measurement. J. Biol. Chem. $61: 523$

7. Shadle, O. W., T. B. Ferguson, D. E. Gregg, and S. R. Gilford. 1953. Evaluation of a new cuvette densitometer for determination of cardiac output. Circ. Res. 1: 200.

8. Liang, C. 1971. Mechanisms Regulating the Cardiac Output Response to Cyanide in Dogs, a Model of $\mathrm{Hy}$ - 
poxia. Ph.D. dissertation, Boston University Graduate School, Boston. Diss. Abstr. Int. B Sci. Eng. 32: 2312B.

9. Huckabee, W. E. 1956. Control of concentration gradients of pyruvate and lactate across cell membranes in blood. J. Appl. Physiol. 9: 163.

10. Hickam, J. B., and R. Frayser. 1949. Spectrophotometric determination of blood oxygen. J. Biol. Chem. 180: 457.

11. Polonovski, M., H. Schmitt, and A. Pelou. 1952. Activité adrénolytique et sympatholytique d'un dérivé de la dibenamine, la N-phénoxyisopropyl-N-benzyl- $\beta$ chloréthylamine. C. R. Seances Soc. Biol. Fil. 146: 1560.

12. Green, H. D., A. B. Denison, Jr., W. O. Williams, Jr., A. H. Garvey, and C. G. Tabor. 1954. Comparison of the potency of dibenzyline, Ilidar, phentolamine (Regitine) and tolazoline (Priscoline) in blocking the vasoconstrictor responses in canine muscle to lumbar sympathetic stimulation and to intra-arterial injections of 1-epinephrine and of 1-norepinephrine. J. Pharmacol. Exp. Ther. 112: 462.

13. Stone, C. A., M. L. Torchiana, A. Navarro, and K. H. Beyer. 1956. Ganglionic blocking properties of 3-methylaminoisocamphane hydrochloride (mecamylamine): a secondary amine. J. Pharmacol. Exp. Ther. 117: 169.

14. Boura, A. L. A., and A. F. Green. 1959. The actions of bretylium: adrenergic neurone blocking and other effects. Br. J. Pharmacol. Chemother. 14: 536.

15. Aviado, D. M., and A. H. Dil. 1960. The effects of a new sympathetic blocking drug (bretylium) on cardiovascular control. J. Pharmacol. Exp. Ther. 129: 328.

16. Gilmore, J. P., and J. H. Siegel. 1962. Mechanism of the myocardial effects of bretylium. Circ. Res. 10: 347.

17. Ledsome, J. R., and R. J. Linden. 1964. The effect of bretylium tosylate on some cardiovascular reflexes. J. Physiol. (Lond.). 170: 442.

18. Flacke, J. W., P. F. Osgood, and H. H. Bendixen. 1967. Propranolol and isoproterenol in dogs deprived of sympathetic nerve activity. J. Pharmacol. Exp. Ther. $158: 519$.

19. Snedecor, G. W., and W. G. Cochran. 1967. Statistical Methods. Iowa State University Press. Ames, Ia. Sixth edition. 94.

20. Kramer, C. Y. 1956. Extension of multiple range tests to group means with unequal numbers of replications. Biometrics. 12: 307.

21. Warburg, O. H. 1949. Heavy Metal Prosthetic Groups and Enzyme Action; translated by A. Lawson. Clarendon Press, Oxford, England. 67.

22. Dixon, M., and E. C. Webb. 1964. Enzymes. Academic Press Inc. New York. Second edition. 337.

23. Barcroft, J., H. A. Harris, D. Orahovats, and R. Weiss. 1925. A contribution to the physiology of the spleen. J. Physiol. (Lond.). 60 : 443.

24. Feldberg, W., and H. Lewin. 1928. Versuche über Milz und Blutvolumen. Pflügers Arch. Gesamte Physiol. Menschen Tiere. 219: 246.

25. Kramer, K., and U. C. Luft. 1951. Mobilization of red cells and oxygen from the spleen in severe hypoxia. Am. J. Physiol. 165 : 215.

26. Meesmann, W., and J. Schmier. 1955. Uber das Versagen des Herzens bei überkritischer Coronardrosselung. Pflügers Arch. Gesamte Physiol. Menschen Tiere. 261: 41.

27. Meesmann, W., and J. Schmier. 1956. Auswirkungen einer elektrischen Milznervenreizung auf die Coronardurchblutung. Pflügers Arch. Gesamte Physiol. Menschen Tiere. 263 : 293.
28. Meesmann, W., and J. Schmier. 1956. Sauerstoffverbrauch des Herzens im "Milz-Leber-Mechanismus". Pflügers Arch. Gesamte Physiol. Menschen Tiere. 263: 304.

29. Peart, W. S. 1949. The nature of splenic sympathin. J. Physiol. (Lond.). 108: 491.

30. Euler, U. S. von. 1954. Adrenaline and noradrenaline. III. Epinephrine and norepinephrine. Distribution and action. Pharmacol. Rev. 6: 15.

31. Brown, G. L., and J. S. Gillespie. 1957. The output of sympathetic transmitter from the spleen of the cat. J. Physiol. (Lond.). 138: 81 .

32. Meesmann, V. W., and J. Schmier. 1956. Herz- und Kreislaufwirkungen korpereigener Stoffe im Vergleich zu den Auswirkungen des "Milz-Leber-Mechanismus”. Z. Kreislaufforsch. 45: 335.

33. Gilmore, N., J. R. Vane, and J. H. Wyllie. 1968. Prostaglandins released by the spleen. Nature (Lond.). 218: 1135.

34. Davies, B. N., E. W. Horton, and P. G. Withrington. 1968. The occurrence of prostaglandin $E_{2}$ in splenic venous blood of the dog following splenic nerve stimulation. Br. J. Pharmacol. Chemother. 32: 127.

35. Ferreira, S. H., and J. R. Vane. 1967. Prostaglandins: their disappearance from and release into the circulation. Nature (Lond.). 216: 868.

36. Cobbin, L. B., and R. H. Thorp. 1959. The cardio-active principle in spleen. Br. J. Pharmacol. Chemother. 14: 392.

37. Thorp, R. H. 1970. A cardiac stimulant functioning by calcium transport. In Proceedings of the Fourth International Congress of Pharmacology. R. Eigenman, editor. J. B. Lippincott Co., Philadelphia. 3: 133.

38. Guntheroth, W. G., G. A. McGough, and G. L. Mullins. 1967. Continuous recording of splenic diameter, vein flow, and hematocrit in intact dogs. Am. J. Physiol. 213: 690 .

39. Bülbring, E., J. H. Burn, and F. J. De Elio. 1948. The secretion of adrenaline from the perfused suprarenal gland. J. Physiol. (Lond.). 107 : 222.

40. Malmejac, J. 1964. Activity of the adrenal medulla and its regulation. Physiol. Rev. 44 : 186.

41. Rubin, R. P. 1969. The metabolic requirements for catecholamine release from the adrenal medulla. $J$. Physiol. (Lond.). 202 : 197.

42. Cannon, W. B., J. R. Linton, and R. R. Linton. 1924 Conditions of activity in endocrine glands. XIV. The effects of muscle metabolites on adrenal secretion. $\mathrm{Am}$. J. Physiol. 71: 153.

43. Dreisbach, R. H. 1966. Handbook of Poisoning: Diagnosis and Treatment. Lange Medical Publications. Los Altos, Calif. Fifth edition. 196.

44. Korner, P. I., and S. W. White. 1966. Circulatory control in hypoxia by the sympathetic nerves and adrenal medulla. J. Physiol. (Lond.). 184: 272.

45. Ashkar, E., and W. F. Hamilton. 1963. Cardiovascular response to graded exercise in the sympathectomizedvagotomized dog. Am. J. Physiol. 204: 291.

46. Richardson, D. W., H. A. Kontos, A. J. Raper, and J. L. Patterson, Jr. 1967. Modification by beta-adrenergic blockade of the circulatory responses to acute hypoxia in man. J. Clin. Invest. 46: 77.

47. Epstein, S. E., B. F. Robinson, R. L. Kahler, and E Braunwald. 1965. Effects of beta-adrenergic blockade on the cardiac response to maximal and submaximal exercise in man. J. Clin. Invest. 44: 1745.

Cardiac Output Regulation in Hypoxia 
48. McKenna, D. H., R. J. Corliss, S. Sialer, W. C. Zarnstorff, C. W. Crumpton, and G. G. Rowe. 1966. Effect of propranolol on systemic and coronary hemodynamics at rest and during simulated exercise. Circ. Res. 19: 520.

49. Ashkar, E. 1965. Circulatory response to exercise in vagotomized dogs with partial sympathectomy. Acto Physiol. Latinoam. 15: 344.

50. Ashkar, E. 1965. Circulatory changes during exercise in denervated dogs with intact splanchnic nerves. Acto Physiol. Latinoam. 15 : 351.

51. Ashkar, E., J. J. Stevens, and B. A. Houssay. 1968. Role of the sympathicoadrenal system in the hemodynamic response to exercise in dogs. Am. J. Physiol. $214: 22$.

52. Donald, D. E., and J. T. Shepherd. 1963. Response to exercise in dogs with cardiac denervation. Am. J. Phys iol. $205: 393$.

53. Barcroft, J., C. D. Murray, D. Orahovats, J. Sands, and R. Weiss. 1925. The influence of the spleen in carbon monoxide poisoning. J. Physiol. (Lond.). 60: 79.

54. Kendrick, D. B., Jr., and A. Uihlein. 1942. Shock in control and splenectomized animals under ether and pentobarbital sodium anesthesia. Surgery. 12: 76

55. Lewis, R. N., J. M. Werle, and C. J. Wiggers. 1942
The behavior of the spleen in hemorrhagic hypotension and shock. Am. J. Physiol. 138: 205.

56. Ask-Upmark, E. 1935. The remote effects of removal of the normal spleen in man. Sven. Läk.-Sällsk. Handl. $61: 197$.

57. Franciscis, P. de, and B. Guidetti. 1947. Ricerche sulla fisiologia della milza nell'uomo. Progr. Med. (Rome). 3: 293.

58. Ek, J. I., and S. Rayner. 1950. An analytical study of splenectomised cases after traumatic rupture of healthy spleens. Acta Med. Scand. 137: 417

59. Fuhs, H. 1956. Milzverletzungen beim Gesunden und ihre Folgen. Monatsschr. Unfallheilk. Beihft. 52: 176.

60. Beck, W. 1956. Die Verletzung der Milz, ihre Versorgung und ihr Endausgang. Monatsschr. Unfallheilk. Beihft. 52: 189.

61. Parhofer, R., K. Tauber, and H. Keyssler. 1960. Nachuntersuchungen über die körperliche Leistungsfähigkeit nach traumabedingten Splenektomien. Bruns' Beitr. Klin. Chir. 200: 492.

62. Focke, W. 1954. Spätuntersuchungen nach Milzentfernung beim Gesunden. Zentralbl. Chir. 79: 965.

63. Hermanuz, N., and O. Westerberg. 1956. Das Herzund Kreislaufsystem nach alten Milz- und Leberverletzungen. Monatsschr. Unfallheilk. Beihft. 52: 193. 